\title{
HASIL BELAJAR MATEMATIKA SISWA KELAS III SDN 01 ELLA HILIR MENGGUNAKAN STRATEGI INSIDE-OUTSIDE CIRCLE (IOC)
}

\author{
Haryati $^{1}$, M. Akip ${ }^{2}$, Eko Rudiansyah ${ }^{3}$ \\ ${ }^{1}$ Mahasiswa Lulusan Program Studi PGSD 2019 \\ ${ }^{2,3}$ Dosen STKIP Melawi
}

Jl. RSUD Melawi km. 04 Kec.Nanga Pinoh Kab. Melawi Kalimantan Barat Hariyatimelawi@gmail.com, m.akip.stkip@gmail.com, ekorudiansyah90@gmail.com

\begin{abstract}
The purpose of the study was to improve the learning process and student learning outcomes in mathematics in the class III SDN 01 Ella Hilir Kecamatan Ella Hilir Kabupaten Melawi. The research method uses classroom action research with a strategy inside outside circle with two cycle namely cycle I dan cycle II. Data collection techniques in this study researchers used test techniques and non-test research instruments using written test, observation sheets and documentation sheets.The learning activities increased after using strategy inside-outside circle. Can be seen in the cycle I meeting II get value the percentage of 52,05\% and the meeting II obtain $74,74 \%$. Cycle II meeting I received scores of the percentage of $88,20 \%$. Study results increased seen from the percentage be completed study results students namely cycle I $66,67 \%$ and cycle II $86,67 \%$ as for the increase is $20 \%$. The conclusion of student learning outcomes in cicle I and II it can be conculed that using the inside outside circle strategy to improve student learning outcomes in mathematics subject class III SDN 01 Ella Hilir can be improved.
\end{abstract}

Keywords: Learning Outcomes, strategy inside-outside circle

\begin{abstract}
Abstrak : Tujuan penelitian untuk memperbaiki proses pembelajaran dan hasil belajar siswa pada mata pelajaran matematika kelas III SDN 01 Ella Hilir Kecamatan Ella Hilir Kabupaten Melawi. Metode Penelitian menggunakan penelitian tindakan kelas dengan strategi Inside-Outside Circle dengan dua siklus yakni Siklus I dan siklus II. Teknik pengumpulan data dalam penelitian ini peneliti menggunakan teknik tes dan non tes instrumen penelitian menggunakan tes tertulis, lembar observasi dan lembar dokumentasi. Hasil kegiatan belajar mengajar mengalami peningkatan setelah menggunakan strategi Inside-Outside Circle, dapat dilihat pada siklus I pertemuan pertama memperoleh nilai persentase $52,05 \%$ dan pertemuan kedua memperoleh $74,74 \%$. Siklus II pertemuan pertama memperoleh nilai persentase $88,20 \%$. Hasil belajar siswa meningkat terlihat dari presentase ketuntasan hasil belajar siswa yaitu pada siklus I $66,67 \%$ dan pada siklus II $86,67 \%$ adapun peningkatannya ialah $20 \%$. Kesimpulan dari hasil belajar siswa pada siklus I dan II dapat disimpulkan bahwa menggunakan strategi inside-outside circle untuk meningkatkan hasil belajar siswa pada mata pelajaran matematika kelas III SDN 01 Ella Hilir dapat ditingkatkan.
\end{abstract}

Kata Kunci: Hasil Belajar, Strategi Inside-Outside Circle

$\mathrm{K}$

egiatan belajar dikatakan sebagai proses pembelajaran karena dalam kegiatan belajar terjadinya suatu aktivitas belajar mengajar yang menghasilkan materi informasi untuk melihat kemajuan atau keberhasilan proses pembelajaran. Keberhasilan suatu proses pembelajaran sering dilihat dari hasil belajar siswa yang membuktikan bahwa siswa tersebut telah sukses atau berhasil selama proses pembelajaran dilakukan.

Berdasarkan hasil pengamatan yang dilakukan selama empat hari di SDN 01 Ella Hilir pada tanggal 18 Februari sampai 
21 Februari 2019, adapun masalah yang ditemui antara lain : (1) siswa kurang memperhatikan guru ketika menjelaskan materi pembelajaran; (2) siswa tidak bersemangat ketika guru menjelaskan. Kedua masalah tersebut dikarenakan cara peyampaian guru dalam menjelaskan materi masih berfokus pada membaca materi dan hanya sedikit melibatkan papan tulis. Padahal untuk mata pelajaran matematika sangat penting papan tulis sebagai salah satu media dan strategi lainnya sebagai cara untuk menyampaikan materi kepada siswa, agar siswa lebih fokus dan membuat siswa menjadi semangat pada saat penjelasan materi yang disampaikan; (3) siswa sering keluar masuk kelas; (4) siswa sibuk dengan mainannya; (5) siswa berbicara bukan tentang pelajaran dengan teman sebangkunya. Adapun masalah yang ke 3,4, dan 5 ini disebabkan tidak disiplinnya siswa terhadap aturan ketika pelajaran berlangsung dan kurang tegasnya guru untuk menegur siswa yang melakukan halhal tersebut; (6) guru kurang menguasai kelas, maksudnya adalah kurangnya perhatian dan ketegasan guru kepada siswa menyebabkan kelas menjadi tidak sesuai dengan tujuan pembelajaran; (7) rendahnya hasil belajar siswa pada pelajaran matematika, dikarenakan beberapa masalah yang telah disebutkan diatas. Hasil belajar kognitif siswa dikatakan rendah sebabdilihat dari nilai yang diperoleh ketika mengerjakan soal latihan matematika, secara keseluruhan dari 16 siswa hanya 4 siswa yang mendapatkan nilainya tuntas berdasarkan standar Kriteria Keberhasilan Minimum (KKM) yang telah ditentukan di sekolah tersebut yaitu 65. Artinya ada 12 siswa yang nilainya tidak tuntas atau tidak mencapai standar KKM.

Melihat dari hasil belajar kognitif siswa yang rendah di kelas III pada mata pelajaran matematika. Salah satu cara untuk memperbaiki hasil belajar siswa perlu diterapkan strategi yang efektif, salah satunya dangan menggunakan strategi Inside-Outside Circle (IOC) diharapkan bisa mengatasi permasalahan-permasalahan siswa pada saat proses pembelajaran dan terhadap hasil belajar siswa. Karena dalam kegiatan belajar mengajar tidak dilakukan oleh satu pihak saja maka perlunya kesadaran dari siswa maupun guru untuk memperbaiki kualitas belajar yang berkaitan dengan hasil belajar siswa.

Metode atau strategi pembelajaran yang guru gunakan kurang bisa meningkatkan hasil belajar siswa terhadap mata pelajaran matematika maka perlu ada kreativitas guru untuk menggunakan metode atau strategi yang dapat meransang siswa banyak terlibat dalam kegiatan pembelajaran dan lebih mudah siswa pahami serta lakukan. Adapun strategi yang diterapkan adalah strategi Inside-Outside Circle (IOC) sebagai cara dalam mengajar 24| J P D, p- I S S N : 2252-8156, e - I S S N : 2579 -3993 
pada mata pelajaran matematika kelas III SDN 01 Ella Hilir. Karena dengan strategi ini selain bermain siswa juga memiliki banyak kesempatan untuk mengolah informasi dan saling berbagi informasi yang didapatkan. Sehingga siswa akan merasa senang dan semangat untuk menyampaikan informasi yang telah didapatkan. Karena siswa banyak mendapatkan informasi maka dengan mudah siswa akan menjawab soalsoal yang guru berikan.

Perlunya penelitian ini dilakukan untuk menambah kreativitas guru dalam menggunakan strategi pembelajaran dengan strategi Inside-Outside Circle (Ioc). Jika strategi pembelajaran ini diterapkan pada mata pelajaran Matematika siswa kelas III SDN 01 Ella Hilir, maka peneliti berharap akan berpengaruh terhadap hasil belajar kognitif siswa. Sehingga permasalahan yang ditemui dapat teratasi.

\section{METODE PENELITIAN}

Jenis penelitian yang digunakan adalah Penelitian Tindakan Kelas (PTK). Menurut Suhardjono (dalam Arikunto, Suhardjono, Supardi, 2015 : 125) penelitian tindakan kelas adalah penelitian tindakan yang dilakukan oleh guru bekerjasama dengan peneliti (atau dilakukan oleh guru sendiri yang bertindak sebagai peneliti) di kelas guna meningkatkan mutu pembelajaran. Menurut Asrori (2016: 52) dalam penelitian menggunakan model PTK Kemmis dan Taggart yang merupakan pengembangan dari konsep dasar yang diperkenalkan oleh Kurt Lewin yaitu perencanaan, tindakan, observasi dan refleksi.

Pada penelitian tindakan kelas ini yang menjadi subjek penelitian yaitu siswa kelas III SDN 01 Ella Hilir tahun ajaran 2018-2019 di kecamatan Ella Hilir dengan jumlah keseluruhan siswa adalah 15 orang yang terdiri dari 8 siswa laki-laki dan 7 siswa perempuan. Dalam penelitian ini objek penelitiannya adalah tentang meningkatkan hasil belajar siswa pada mata pelajaran matematika menggunakan strategi inside-outside circle kelas III SDN 01 Ella Hilir.

Teknik pengumpulan data yang digunakan dalam penelitian ini menggunakan teknik tes dan non tes (observasi). Menurut Colleggiate (dalam Purwanto 2014: 64), tes adalah serangkaian pertanyaan atau latihan atau alat lain yang digunakan untuk mengukur keterampilan, pengetahuan, intelegensia, kemampuan, atau bakat, yang dimiliki oleh individu atau kelompok. Menurut Sukmadinata (2010: 220), observasi atau pengamatan merupakan suatu teknik atau cara mengumpulkan data dengan jalan mengadakan pengamatan terhadap kegiatan yang sedang berlangsung.

Instrumen adalah alat yang digunakan untuk melakukan penelitian. Sedangkan instrumen penelitian merupakan semua alat e - I S N : 2579 - 3993 
yang digunakan untuk mengumpulkan, memeriksa, menyelidiki suatu masalah, atau mengumpul, mengolah, menganalisa, dan menyajikan data-data secara sistematis dan objektif dengan tujuan memecahkan masalah atau menguji hipotesis dengan menggunakan strategi tertentu. Instrumen yang penulis gunakan yaitu berupa tes tertulis atau lembar hasil kerja siswa (LKS), lembar observasi dan lembar dokumentasi.

\section{HASIL DAN PEMBAHASAN}

\section{Hasil Penelitian}

Hasil penelitian siklus I

Hasil lembar keterlaksanaan RPP siklus I pertemuan I perolehan persentase pada kegiatan awal sebesar 60\%, kegiatan inti 46,15\%, dan kegiatan akhir 50\%. Pertemuan II perolehan persentase pada kegiatan awal sebesar 80\%, kegiatan inti 69,23\%, dan kegiatan akhir 75\%. Jadi rentang kenaikan antara pertemuan I ke pertemuan II pada kegiatan awal sebesar
$20 \%$, kegiatan inti sebesar $23,08 \%$, dan kegiatan akhir sebesar $25 \%$.

Hasil belajar siswa pada siklus I pertemuan pertama dan kedua yang hasil belajarnya digabung kemudian dibagi dua. Kriteria keberhasilan secara individu berdasarkan KKM yaitu 65 dan kriteria keberhasilan secara klasikal yaitu $80 \%$. Maka dapat disimpulkan bahwa dari jumlah keseluruhan siswa 15 orang dapat dikatakan bahwa hasil belajar belum meningkat. Karena jumlah siswa yang tuntas sebanyak 10 orang, tidak tuntas 5 orang dan persentase ketuntasan hanya $66,67 \%$.

Hasil penelitian siklus II

Hasil lembar keterlaksanaan RPP siklus II pertemuan I perolehan persentase pada kegiatan awal sebesar $80 \%$, kegiatan inti $80 \%$, dan kegiatan akhir 100\%. Pada siklus II pertemuan dilakukan hanya 1 kali, karena pada pertemuan ini persentase yang didapat telah mencapai pada kriteria keberhasilan yang ditentukan.

Tabel 1 Data hasil lembar keterlaksanaan RPP siklus 1I

\begin{tabular}{lccc}
\hline \multicolumn{1}{c}{ Nama kegiatan } & $\begin{array}{c}\text { Skor } \\
\text { perolehan }\end{array}$ & $\begin{array}{c}\text { Skor } \\
\text { maksimal }\end{array}$ & Persentase \\
\hline Kegiatan pendahuluan & 4 & 5 & $80 \%$ \\
Kegiatan inti & 12 & 15 & $80 \%$ \\
Kegiatan penutup & 4 & 4 & $100 \%$ \\
\hline Rata-rata & & & $86,67 \%$ \\
\hline
\end{tabular}


Kriteria keberhasilan secara individu berdasarkan KKM yaitu 65 dan kriteria keberhasilan secara klasikal yaitu $80 \%$. Maka berdasarkan tabel 4.4 dapat disimpulkan bahwa dari jumlah keseluruhan siswa 15 orang dapat dikatakan bahwa hasil belajarmeningkat. Karena jumlah siswa yang tuntas sebanyak 13 orang, tidak tuntas 2 orang dan persentase ketuntasan hanya 86,67\% dengan demikian penelitian ini dapat dikatakan berhasil. Dari pengolahan data tersebut dapat peneliti simpulkan bahwa pada siklus II hasil belajar siswa setelah menggunakan strategi inside-outside circle sudah meningkat atau telah memenuhi kriteria yang telah ditentukan, maka dari itu peneliti tidak melanjutkan pada pertemuan selanjutnya. Berikut tabel perbandingan hasil belajar siswa pada siklus I dan siklus II:

Tabel 2 Perbandingan Hasil Belajar Siswa Pada Siklus I dan Siklus II

\begin{tabular}{ccccc}
\hline Siklus & $\begin{array}{c}\text { Jumlah } \\
\text { siswa } \\
\text { tuntas }\end{array}$ & persentase & $\begin{array}{c}\text { Jumlah siswa } \\
\text { tidak tuntas }\end{array}$ & Persentase \\
\hline I & 10 & $66,67 \%$ & 5 & $33,33 \%$ \\
\hline II & 13 & $86,67 \%$ & 2 & $12,33 \%$ \\
\hline
\end{tabular}

\section{Pembahasan}

Berdasarkan data yang diperoleh selama melakukan penelitian, dapat diketahui penilaian keterlaksanaan pembelajaran guru pada siklus I pertemuan pertama ini, yang terdiri dari kegiatan awal memperoleh nilai persentase $60 \%$, kegiatan inti $46,15 \%$, kegiatan akhir 50\% dengan total nilai rata-rata $52,05 \%$. Penilain proses pembelajaran guru pada siklus I pertemuan kedua ini yang terdiri dari kegiatan awal memperoleh nilai persentase $80 \%$, kegiatan inti 69,23\%, kegiatan akhir $75 \%$ dengan total rata-rata $74,74 \%$.

Pada siklus II pertemuan pertama atas penilaian keterlaksanaan pembelajaran guru pada siklus II pertemuan pertama ini yang 27| J P D, p-I S S N : 22 $252-8156$, e - I S S N : 2579 - 3993 terdiri dari kegiatan awal memperoleh nilai persentase $80 \%$, kegiatan inti $84,61 \%$, kegiatan akhir $100 \%$ dengan total rata-rata $88,20 \%$, proses pelaksanaan pembelajaran sudah baik serta sesuai dengan Rencana Pelaksanaan Pembelajaran (RPP). Pada pertemuan ini proses pembelajaran sudah mencapai kriteria keberhasilan yang telah ditetapkan peneliti yaitu apabila keterlaksanaan kegiatan belajar mengajar telah mencapai $80 \%$.

Jadi dapat peneliti simpulkan persentase yang diperoleh pada siklus I ke siklus II mengalami peningkatan $74,74 \%$ menjadi 88,20\% dengan kriteria sangat baik atau dikatakan berhasil. 
Hasil tes siklus II dari siswa yang berjumlah 15 orang dapat dikatakan bahwa hasil belajar sudah meningkat. Jumlah siswa yang tuntas pada siklus II ini yaitu $86,67 \%$ dari kriteria yang sudah ditetapkan yaitu $80 \%$. Hal ini dapat dilihat dari jumlah siswa yang mendapat nilai tuntas sebanyak 13 orang siswa dan yang tidak tuntas sebanyak 2 orang siswa dengan nilai kriteria yang telah ditentukan yaitu 65, artinya siswa yang mendapat nilai $\geq 65$ ada 13 orang siswa dan yang mendapat nilai $\leq 65$ ada 2 orang siswa.

Dari pengolahan data di atas dapat peneliti simpulkan bahwa pada siklus II hasil belajar siswa setelah menggunakan strategi inside-outside circle sudah meningkat atau memenuhi kriteria yang telah ditentukan yaitu $80 \%$ yang nilainya $\geq 65$ dengan demikian dapat dikatakan berhasil.

Jadi dapat disimpulkan bahwa kondisi belajar siswa pada tahapan siklus I dan siklus II telah memenuhi kriteria yang telah ditetapkan hasil belajar siswa mengalami peningkatan dari siklus I ke siklus II yaitu $66,67 \%$ ke $86,67 \%$ yaitu $20 \%$ dengan demikian disimpulkan bahwa strategi inside-outside circle mata pelajaran matematika siswa kelas III SDN 01 Ella Hilir, Kec. Ella Hilir dikatakan berhasil.

\section{SIMPULAN}

Berdasarkan seluruh pembahasan serta analisis yang telah dilakukan dapat disimpulkan bahwa pembelajaran dengan menggunakan strategi inside-outside circle untuk meningkatkan hasil belajar siswa pada mata pelajaran matematika kelas III dapat meningkat. Pada Siklus I presentase kriteria keberhasilan hanya mencapai $66,67 \%$, hal ini penelitian belum berhasil. Dikatakan berhasil jika hasil belajar secara klasikal apabila $80 \%$ dari jumlah siswa telah mencapai kriteria minimal 65. Pada siklus II hasil belajar semakin meningkat dengan presentase kriteria keberhasilan mencapai $86,67 \%$, penelitian ini berhasil karena secara klasikal $80 \%$ dari jumlah siswa sudah mencapai kriteria minimal 65, sehingga penelitian ini dihentikan pada siklus II.

\section{DAFTAR PUSTAKA}

Arikunto, S. dan Suhardjono. 2015. Penelitian Tindakan Kelas. Jakarta : PT Bumi Aksara.

Asrori, M. 2016. Penelitian Tindakan Kelas. Bandung : CV Wacana Prima. Nana Syaodih Sukamadinata. 2010. Metode Penelitian Pendidikan. Bandung : PT Remaja Rosdakarya.

Purwanto. 2008. Evaluasi Hasil Belajar. Yogyakarta : Pustaka Pelajar.

Purwanto. 2010. Evaluasi Hasil Belajar. Yogyakarta: Pustaka Pelajar. 